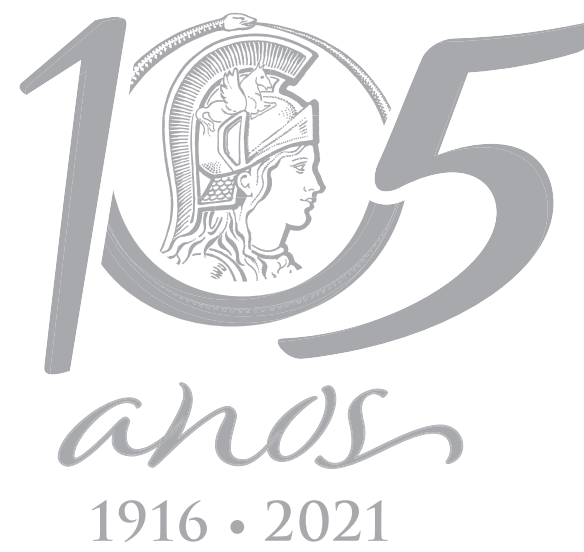

\title{
MICROBIOLOGY
}

\section{Bioprospection of ligninolytic enzymes from marine origin filamentous fungi}

\author{
CAMILA P. DANTAS, JOÃO PEDRO D. PINCHEMEL, GISELE M. DE JESUS, MILENA \\ B. PIMENTEL, OLIVIA MARIA C. OLIVEIRA, ANTÔNIO FERNANDO S. QUEIROZ \& \\ DANUSIA F. LIMA
}

\begin{abstract}
Fungi are excellent producers of extracellular enzymes. Therefore, the present study aimed to investigate the screening of marine fungi, which are laccase and manganese peroxidase potential producers, in solid fermentation for future applications in bioremediation processes of contaminated sites. For this purpose, twolevel factorial planning was adopted, using time ( 6 and 15 days) and the absence or presence of oil ( 0 and $1 \%$ ) as factors. The semi-quantitative evaluation was carried out by calculating radial growth, enzyme activity and enzyme index by measuring phenol red or syringaldazine oxidation halo. The results showed that all the studied strains showed a positive result for manganese peroxidase production, with an enzymatic activity in solid medium less than 0.61 , indicating a strongly positive activity. Through the enzyme index, the study also showed prominence for Penicillium sp. strains, with values $>2$. The enzyme index increase in oil presence and the inexpressive use of the genera studied for ligninolytic enzymes production from crude oil demonstrated these data importance for fermentative processes optimization. Considering the ability of these strains to develop into recalcitrant compounds and the potential for manganese peroxidase production, they are indicated for exploitation in various bioremediation technologies, as well as other biotechnological applications.
\end{abstract}

Key words: bioremediation, enzymatic activity, manganese peroxidase, mycoremediation.

\section{INTRODUCTION}

The production of enzymes from microorganisms exposes great biotechnological, industrial and environmental interest due to its wide catalytic activities variety, large-scale production possibility, adaptation ease, renewability capacity and propensity for socioeconomic and environmental merits (Behbudi et al. 2021). Therefore, ligninolytic enzymes have a background for white biotechnology, with great potential for generating bio-products with high added value from natural biomass, following the green agenda (Bilal \& Iqbal 2020).
Ligninolytic enzymes (LES) are made up of three main representatives: lignin peroxidase (LiP, EC 1.11.1.14), manganese peroxidase (MnP, EC 1.11.1.13) and laccase (Lac, EC 1.10.3.2), along with others accessory enzymes (Wong 2009) and have the function of catalyzing modifications or degrading lignin into less complex molecules (Asemoloye et al. 2020). These enzymes have great versatility that covers a wide spectrum of use in bioremediation, and it is pointed out its complex recalcitrant compounds degradation and mineralization capacity, such as petroleum compounds and their derivatives (Asemoloye et al. 2020), pesticides (Zeng et al. 2017), drugs, such as endocrine disrupters (Eldridge et al. 2017) 
and polycyclic non-steroidal anti-inflammatory drugs (Bankole et al. 2021), synthetic fragrances (Vallecillos et al. 2017), lignocellulosic residues (Kumar \& Chandra 2020) textile effluent dyes (Rather et al. 2018) and also allows biocatalytic plastic recycling (Wei \& Zimmermann 2017), bleaching paper (Nathan et al. 2018) and biosensors production (Sidwaba et al. 2019) among others. Most residues cited above have in their composition compounds that can cause adverse effects to the natural environment and to humans, among them polycyclic aromatic hydrocarbons (PAHs), formed by two or more condensed aromatic rings and responsible for several biological effects, such as high toxicity, mutagenicity and carcinogenic potential (Kadri et al. 2017).

The bioremediation use as a strategy for affected areas recovery has advantages in being an ecologically correct and cheaper technique when compared to chemical and physical methods of remediation (Kurniati et al. 2014). In recent years, interest in using fungi ligninolytic system as bioremediation agents has grown exponentially (Rao et al. 2014). This interest is mainly due to its oxidative efficiency, sustainable character, its low specificity to the substrate, feasibility of improving its production, stability and activity, and the possibility of immobilizing them when the use of microorganisms is limited (Ogola et al. 2015).

Many Aspergillus sp. and Penicillium sp. fungi species are reported in literature as efficient in natural environments contaminated by organic pollutants bioremediation through extracellular production of LEs (Li et al. 2020). Marine environments are an extraordinary source of microorganisms diversity capable of adapting to extreme conditions, therefore their enzymes are very attractive in unusual bioprocesses (Theerachat et al. 2019). Thus, marine origin fungi have great potential for industrial application, once they are capable of producing enzymes with different physiological characteristics, such as tolerance to high rates of salinity and $\mathrm{pH}$, high pressures, thermostability, psychrotolerance, thermostability and barophilicity (BonugliSantos et al. 2015).

The demand for screening studies of new enzymes is a need that extends from today, in order to improve more competitive and sustainable production processes (Adrio \& Demain 2014). It is known that enzymes have different characteristics depending on the species, strains and cultivation conditions, therefore, although they have been extensively isolated and characterized from different natural sources, enzymes production system is a limitation for further large scale and reduced cost exploration (Sharma et al. 2018). In this sense, it is understood that for industrial processes development aiming enzymes production, initially the isolation and selection of microorganisms potentially producing enzymes with biotechnological interest is required, making bioprospecting studies fundamental (Paludo et al. 2019).

The use of simple methods can be effective in microorganisms characterization and configure a quick and useful screening when evaluating individual fungi (Hankin \& Anagnostakis 1975). The direct correlation of radial growth diffusion and oxidation halo formed in solid culture medium can be used to determine the activity of extracellular enzymes (Ceska 1971). Thus, the selection of undesirable compound degrading fungi through their enzymatic activity represents a viable evaluation strategy for obtaining promising biotechnology industry microorganisms. (Lin et al. 1991). Therefore, the present work aims to screen marine origin filamentous fungi that are laccase and manganese peroxidase potential producers in solid fermentation for 
future bioremediation processes applications in hydrocarbon contaminated sites.

\section{MATERIALS AND METHODS}

\section{Strains}

Five strains of filamentous fungi isolated from mangrove sediment in the Todos os Santos Bay, Brazil were obtained from the library of the Centro de Excelência em Geoquímica do Petróleo (LEPETRO) at the Federal University of Bahia. Data derived from phylogenetic analyzes (Supplementary Material - Figure S1 and Table $\mathrm{SI}$ ) identified these fungi as Aspergillus sp. (R16), Penicilium sp. 1 (S40), Penicilium sp. 2 (R31), Penicilium sp. 1 (R26) and Byssochlamys sp. (N89). These microorganisms were selected for their ability to tolerate / degrade petroleum hydrocarbons (Lima et al. 2017, 2018) and therefore constitute a mixed microbial consortium protected by the patent with deposit number BR 1020210023414 (Lima et al. 2021), at the Instituto Nacional de Propriedade Industrial (INPI) and endorsed at the National Biotechnology Information Center (NCBI) under access numbers MW855899, MW855902, MW855901, MW855900, MW855903, respectively. They were grown on Sabouraud Dextrose Agar (SDA) (Kasvi ${ }^{\circledR}$, Brazil) and maintained at $4{ }^{\circ} \mathrm{C}$ for further analysis.

\section{Plaque screening test}

The production capacity of lignolytic enzymes was determined from the oxidation of specific compounds present in the culture medium (Agrawal et al. 2017), where the $0.1 \%$ ( $\mathrm{m} / \mathrm{v}$ ) syringaldazine solution was used for Lacase (Lac) and the $2 \mathrm{mM} \mathrm{MnSO}_{4}$ solution and $0.1 \%$ (w / v) phenol red (Sigma-Aldrich ${ }^{\circledR}$ ) for Manganese peroxidase $(\mathrm{MnP})$ according to guidelines adapted from the method described by Szklarz et al. (1989) and Kuwahara et al. (1984), respectively. One disc $(1 \mathrm{~cm} \phi)$ of pure colonies from each fungus was inoculated in the center of the Petri dish containing the Bushnell Haas medium (BH) (Difco ${ }^{\circledR}$, United States) plus 1\% (v / v) of oil from the Recôncavo basin sterilized in UV for $15 \mathrm{~min}$, for condition I and in the culture medium Sabouraud Dextrose Agar (SDA) (Kasvi ${ }^{\circledR}$, Brazil) for condition II. Subsequently, the strains were incubated at $30{ }^{\circ} \mathrm{C}$ and changes were observed for 15 days.

\section{Enzyme index calculation}

The identification of positive enzymatic reactions occurred through the formation of a discoloration halo around the colonies. The semi-quantitative determination of the enzymatic potential was evaluated by measuring the diameter of the halo produced and the radial growth of the colony with a millimeter rule. The data were initially submitted to the calculation of the enzymatic index (IE), which reflects the ratio of the diameter of the halo to the diameter of the colony (Hankin \& Anagnostakis 1975) and subsequently the enzymatic activity $(\mathrm{Pz})$ which corresponds to the ratio between the mean value the growth zone and the total growth zone plus oxidation of each strain (Price et al. 1982). Pz is classified and coded from the values obtained, where: it is considered negative when equal to 1, Pz = class 1; positive when $<1>0.64, \mathrm{Pz}$ = class 2 and strongly positive when $<0.64, \mathrm{Pz}=$ class 3 (Queiroz \& De Souza 2020).

\section{Experimental design}

The factorial design adopted was $2^{2}$, with two replicates totaling 4 experiments for each strain. Two levels related to the lowest (-1) and highest (1) were adopted, where 6 and 15 days are related to time (factor 1) and 0 and 1 are for the absence of oil (factor 2). These experiments were carried out to predict better conditions for the fungi's ligninolytic enzyme index as a function of time 
and the presence or absence of oil in the culture medium.

\section{Statistical Analysis}

The experiment was conducted with random sampling, with repetitions for each strain and cultivation condition. The data obtained were analyzed using the Minitab software version 20.2.0.0, where factor planning and normality and homogeneity tests of variance were applied, considering a value of $p \leq 0.05$.

\section{RESULTS AND DISCUSSION}

As shown in figure 1, the strains when grown in $\mathrm{BH}$ medium corrected with manganese sulfate and phenol red became colorless, showing complete degradation of phenol red, in SDA medium the reaction was reversed from colorless to red in different shades. On the other hand, there was no change in culture media color which syringaldazine was used as a standard substrate (data not shown) for Lac. Therefore, the results obtained by observing the discoloration halo,

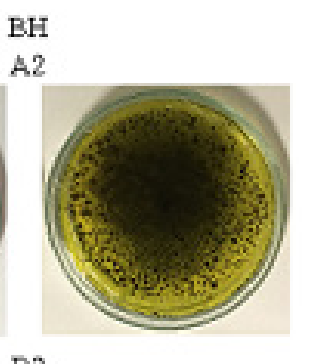

Figure 1. Phenol red discoloration halo seen from back by fungal strains in SDA medium (1) and BH medium (2) in 1 day and after 15 days of incubation. a) Aspergillus sp. b) Penicilium sp. 1 c) Penicilium sp. 2 d) Penicilium sp. 1(R26) e) Byssochlamys sp.

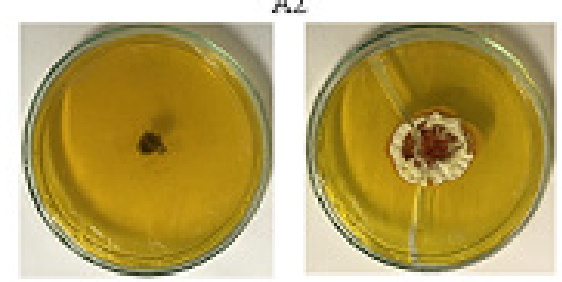

$\mathrm{C} 1$
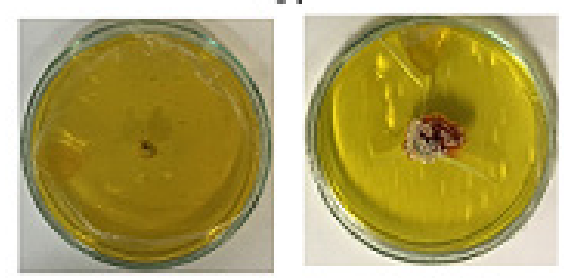

D1
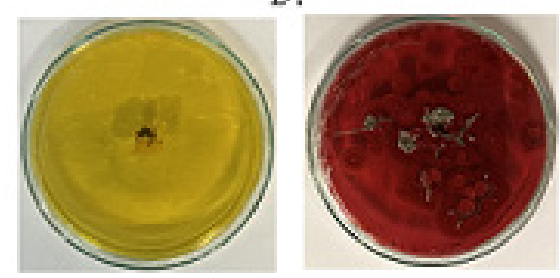

E1
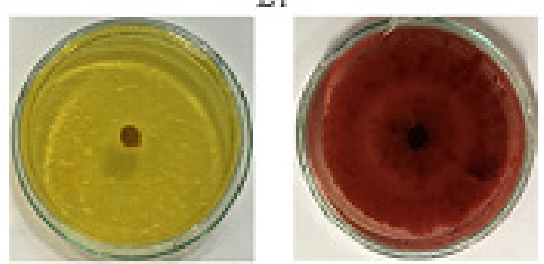

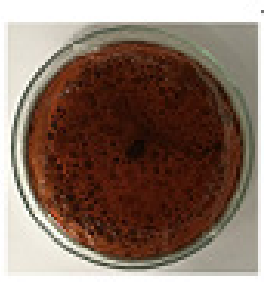

B2

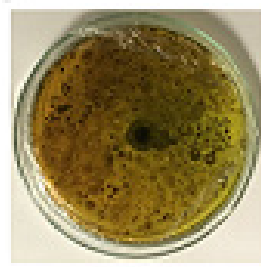

$\mathrm{C} 2$
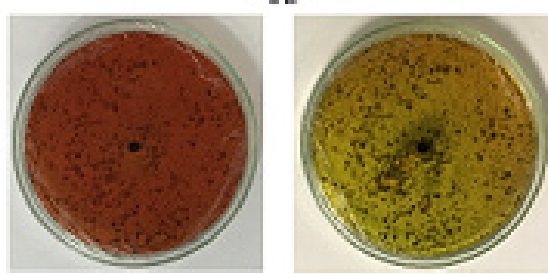

D2
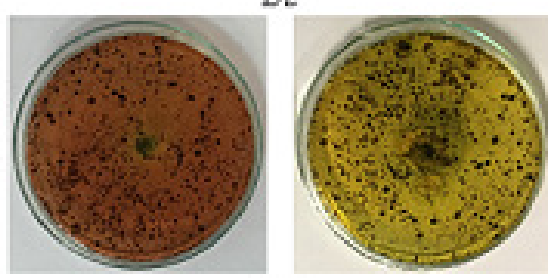

E2

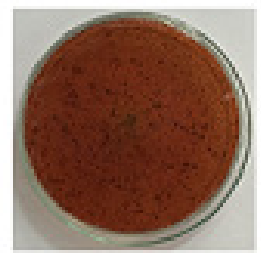

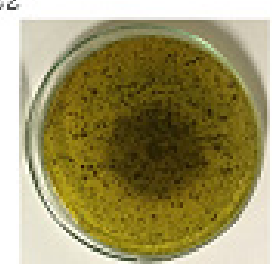


shown in Fig. 1, demonstrated that Aspergillus sp., Penicilium sp. 1, Penicilium sp. 2, Penicilium sp. 1(R26). and Byssochlamys sp. has the capacity to produce manganese peroxidase in a solid culture medium, however it did not show activity for Lacase. The same result was found by Vipotnik et al. (2021), where it was not possible to detect Lac for P. chrysogenum in 2 weeks of incubation in solid fermentation under the influence of $\mathrm{pH} 7$.

Lignolytic enzymes production is influenced by several factors, such as carbon and nitrogen source, growth conditions and the effect of aromatic compounds (Schneider et al. 2018), as well as genetic, physiological or ecological specificities of each fungus (Elisashvili et al. 2010). It is known that catalytic activity requires the presence of cofactors, such as metals and coenzymes, as well as an ideal $\mathrm{pH}$ range, so their absence can affect the production and activity of enzymes (Coelho et al. 2008). In this sense, it can be inferred that, probably, the cultivation conditions were not satisfactory for laccase production, since the ideal $\mathrm{pH}$ for production in P. cyclopium and P. digitatum was considered acid close to 5 and temperature of $25^{\circ} \mathrm{C}$ (El-Shora et al. 2008), different from what was carried out in this study, $\mathrm{pH} 7$ and $6 \pm 0.2$ at $30^{\circ} \mathrm{C}$ for $\mathrm{BH}$ and SDA, respectively. On the other hand, the results found in Kumar et al. (2016) are divergent, since $P$. martensii obtained optimum laccase production conditions at $35^{\circ}$ $\mathrm{C}$ in a $\mathrm{pH} 7$, indicating optimum conditions variation for each strain. As for the genus Aspergillus, A. flavus Lac production was found from in solid medium, both at acidic $\mathrm{pH}$ and at $\mathrm{pH}$ close to neutrality ( $\mathrm{pH}$ from 3.5 to 7.5 ) and in temperature variations of $20^{\circ} \mathrm{C}$ at $35^{\circ} \mathrm{C}$ (Aftab et al. 2018). Notwithstanding were the results of $\mathrm{Hu}$ et al. (2011), where he obtained enzymatic activity for Lac in A. niger and A. oryzae, both in individual culture and in co-cultivation at $25^{\circ} \mathrm{C}$ or $30^{\circ} \mathrm{C}$ in a pH 6.0. One of the major differences between the works mentioned and the current one is in substrate, for this reason we can infer that, although it was possible to observe the production of Lac by other authors at $\mathrm{pH}$ 7, the optimal pH also depends on the substrate used (Fukushima \& Kirk 1995). In this sense, once most fungi laccases are preferably produced at a $\mathrm{pH}$ close to 3 using 2,2'-Azino-Bis (ABTS) as a substrate (Kumar et al. 2016), it is believed that syringaldazine can also be similar and therefore resulted in the non-detection of Lac in the conditions provided. Furthermore, $\mathrm{pH}$ in acidic conditions can favor the development of filamentous fungi and assist hydrocarbons degradation (Maciel et al. 2010). Regarding Byssochlamys genus, although it is widely used in bioremediation strategies (Mann et al. 2010, Hechmi et al. 2016) some species, such as $B$. nivea are not able to produce the enzyme laccase or lignin peroxidases (Bosso et al. 2015), which corroborates our findings.

Laccase has a limited effect on bioremediation due to its specificity forlignin phenolic units and thus some substrates cannot be directly oxidized by Lac (Theerachat et al. 2019), in these cases the limitation can be overcome with the addition of mediators, as well as some other enzymes, such as: feruloyl esterase, lipases, aryl-alcohol oxidase, catechol 2, 3-dioxigenase, quinone reductases (Kumar \& Chandra 2020). Thus, it is necessary to optimize the adaptable subtract condition to these fungi, as well as to test different redox mediators concentrations, such as 2,20-azino-bis and p-cumárico acid, 1-hydroxybenzotriazol (Bankole et al. 2021) or the inclusion of inductors, such as copper sulfate (De Salas et al. 2019, Ferraroni et al. 2017), ethanol, methanol, isopropanol, acetone, tween 80, glycerin, glucose, triton $\mathrm{X}$, sulfate iron, calcium chloride, sodium nitrate 
(Aftab et al. 2018), in order to improve the target enzyme activity.

Through figure 1 it is possible to observe the culture media color change around the strains colony diameter after 15 days of incubation. Manganese peroxidase is a manganesedependent enzyme, which, from the manganese oxidation enables the subsequent oxidation of phenolic compounds (Glenn et al. 1986). Thus, this enzyme synthesis is indicated through the phenol red oxidation and subsequent color change, as shown in figure 1. The results showed the enzyme presence in all fungi in a culture medium with $1 \%$ oil. This enzyme production in response to crude oil increase in $A$. niger corroborates the data found in Asemoloye et al. (2018), which acquired 70 U. $\mathrm{mL}^{-1}$ of $\mathrm{MnP}$ when produced in $5 \%$ of oil. Similar results were observed in Maciel et al. (2010), using diesel oil as a substrate and reached a production of 60 U.L and 7 U.L for MnP from Penicillium sp. and A. tamarii, respectively. For Byssochlamys genus, 0.17 IU.mL of MnP production was also observed, according to M'barek et al. (2019).

Among fungal peroxidases, MnP has great ecological importance, mainly due its plant biomass conversion and recalcitrant compounds degradation (Kellner et al. 2014). This enzyme is extensively explored biotechnologically because it mediates textile dyes biocatalysis reactions (Zhang et al. 2020), in addition to presenting high petroleum hydrocarbons degradation rates (Becarelli et al. 2019). Therefore, the cited fungi demonstrated ability to secrete $\mathrm{MnP}$, which gives them great potential for environmental and industrial applications, such as pulp and paper industries for bio-bleaching processes, pulp production and effluent purification (Saldarriaga-Hernández et al. 2020) or in the food industry, producing natural aromatic flavors (Li et al. 2015). Furthermore, these enzymes can play a vital role in biofuels production and other biochemicals, since they oxidatively depolymerize lignin and leave the polysaccharides intact (Maciel \& Ribeiro 2010).

Table I describes the enzyme index and the enzyme activity found for manganese peroxidase of studied fungi at the end of 15 days of incubation. The enzymatic activity of $\mathrm{MnP}$ varied between 0.24 and 0.61 , grouping all strains as class 3 . Since the $\mathrm{Pz}$ is less than 0.64 , the strains are classified with strongly positive activity, which is, the lower the value of $\mathrm{Pz}$, the greater the potential for production of the enzyme and therefore should be considered excellent producers of the enzyme in question.

Since Aspergillus sp. showed enzymatic activity of 0.61 and 0.37 in SDA and BH media, respectively, it is believed that it provides favorable characteristics for MnP production and, consequently, bioproducts production. No reports were found in the literature regarding $\mathrm{Pz}$, however it is known that Aspergillus sp. are well known for secreting large amounts of enzymes (Hernández-Martínez et al. 2011) and for this reason they are often mentioned in several studies as efficient producers of lignolytic complex enzymes, among them the work of Reis et al. (2019) where A. niger is cited as a viable alternative production of multiple enzymes, including MnP and Lac. In addition, the A. niger strain can be adopted as a biodegradable agent for complex compounds, such as effluent discoloration composed of reactive yellow and reactive red dye, reaching $98.62 \%$ and $92.42 \%$ removal, respectively, as described by Salem et al. (2019), and as an alternative, A. niger it can also biodegrade the Congo Red dye, reaching a discoloration rate of $97 \%$ as a result ligninolytic enzymes action, where MnP plays a crucial role in discoloration (Asses et al. 2018).

All three Penicillium strains showed favorable results to production $\mathrm{MnP}$, with increasing values of $0.31,0.50,0.53$ on SDA 
Table I. Average and standard deviation of the enzyme index and enzymatic activity of strains for MnP in solid medium in 15 days of incubation.

\begin{tabular}{|c|c|c|c|c|c|c|}
\hline \multirow{2}{*}{ Microorganism } & \multicolumn{2}{|c|}{$\begin{array}{c}\text { Enzymatic Index } \\
\text { (IE) }\end{array}$} & \multicolumn{2}{c|}{$\begin{array}{c}\text { Enzymatic Activity } \\
\text { (Pz) }\end{array}$} & \multicolumn{2}{c|}{$\begin{array}{c}\text { Radial diffusion } \\
\text { (cm) }\end{array}$} \\
\cline { 2 - 7 } & SDA & BH & SDA & BH & SDA & BH \\
\hline Aspergillus sp. & $0.64 \pm 0.03$ & $1.64 \pm 0.21$ & $0.61 \pm 0.01$ & $0.37 \pm 0.03$ & $9.00 \pm 0.00$ & $4.85 \pm 0.21$ \\
\hline Penicilium sp. 1 & $0.97 \pm 0.03$ & $1.85 \pm 0.27$ & $0.50 \pm 0.03$ & $0.35 \pm 0.00$ & $3.50 \pm 0.28$ & $2.00 \pm 0.00$ \\
\hline Penicilium sp. 2 & $0.88 \pm 0.17$ & $3.15 \pm 1.32$ & $0.53 \pm 0.05$ & $0.25 \pm 0.08$ & $2.55 \pm 0.35$ & $2.50 \pm 0.42$ \\
\hline Penicilium sp.1(R26) & $2.21 \pm 0.22$ & $3.18 \pm 0.39$ & $0.31 \pm 0.02$ & $0.24 \pm 0.02$ & $4.10 \pm 0.42$ & $3.00 \pm 0.14$ \\
\hline Byssochlamys sp. & $1.15 \pm 0.02$ & $1.53 \pm 0.14$ & $0.46 \pm 0.00$ & $0.42 \pm 0.02$ & $7.80 \pm 0.14$ & $5.90 \pm 0.56$ \\
\hline
\end{tabular}

media and $0.24,0.25,0.35$ on $\mathrm{BH}$ media. Although the strains potential mentioned, in terms of volume, is not known, many Penicillium fungi have a great consolidated biotechnological role to degrade different compounds, as well as in Govarthanan et al. (2017) work, where he records in his study with Penicillium sp. obtaining $1.0492 \mathrm{U}$ of crude MnP enzyme in the degradation process of decane, butylbenzene, dodecane, naphthalene, acenaphtene, octane, ethylbenzene and benzo [a] pyrene. In contrast, Chen et al. (2019) obtained a production range of 4.68-23.31 U mL ${ }^{-1}$ of MnP from P. simplicissimum on triphenylmethane discoloration. Thus, this statement adds relevance to the isolates studied for the degradation of undesirable aromatic compounds.

Although there are few reports in the literature regarding the production of ligninolytic enzymes by Byssochlamys strains, the genus is mentioned as adapted for development in environments contaminated by hydrocarbons (Radwan et at. 2018) and is often pointed out as responsible for corrosion of metals (Blaney 2007). However, B. nivea is mentioned as efficient in mycoremediation process of sites contaminated by aromatic compounds, such as pentachlorophenol (Hechmi et al. 2016) and metabolizing biodiesel and petroleum diesel (Ye et al. 2017). Representatives of this genus also have genes involved in aromatic compounds and n-alkanes degradation, including cytochrome P450 alkane hydroxylase, cytochrome $\mathrm{P} 450$ monooxygenase, aromatic ringopening dioxygenase, salicylate hydroxylase, 2-haloacidalogenase, benzyl alcohol dehydrogenase, benzoate 4-monooxygenase and dimethylsulfide monooxygenase (Radwan et al. 2018). White rot fungi ability to degrade aromatic compounds is attributed to MnP and Lac activity, which is often focused on Basidiomycota, among them Aspergillus and Penicillium, however Ascomycota representatives such as $B$. nivea are neglected (Hechmi et al. 2016). Therefore, the data from this study may be a stimulus for further investigations regarding these enzymes production from Byssochlamys genus and the strain exploration for bio products productions for white biotechnology.

Enzyme activity index is one of the most used semi-quantitative parameters to evaluate the production of enzymes by microorganisms in a solid medium (Rezende et al. 2013). Based on this assumption, all the studied fungi can be considered manganese peroxidase producers, according to the data shown in Table I. However, 
Aspergillus sp. and Byssochlamys sp. strains showed activity below 2 in SDA and BH medium, on the other hand, Penicillium sp.1 (R26) showed an enzyme index greater than 2 in both media as shown in Table I. It is believed that microorganisms can be considered potentially viable for biotechnological use when they have an enzyme index > 2.0 (Stamford et al. 1998), generating relevance for Penicilium sp.1 (R26). It is assumed that the higher the enzyme index, the greaterthe enzyme production and, consequently, the greater degradation of target compounds. In this sense, the information found may be in agreement with the data presented by Abdullah et al. (2020), which describes indigenous fungi dominance on soil contaminated by crude oil belonging to Penicillium and Aspergillus genus and indicating Penicillium sp. as more efficient in breaking polycyclic aromatic hydrocarbons, reaching levels between $25 \%$ to $32 \%$ compared to $13 \%$ to $19 \%$ when mineralized by Aspergillus sp.

When observing the colony diameter values (Table I), Aspergillus sp. and Byssochlamys sp. showed greater growth, reaching 9.0 and 4.8, 7.8 and 5.9, respectively. Thus, it is noted that colonies with a higher enzyme index were not necessarily the same strains that showed greater radial growth, that is, the microorganism development is not directly proportional to the target enzyme production.

As shown in Figure 2, we can see the experimental design results for all the five strains studied. Time and absence or presence of oil in relation to IE significance were the main effects factors, with factor 2 being more significant, however the interaction factor between them was not statistically significant. Those factors' effect was positive, that is, the longer the time and the presence of oil, the better IE results in Aspergillus sp. and Penicillium sp. 1 (fig. 2.a and 2.b). As for Penicillium sp. 2, only the oil presence showed significance $(p$ value $=0.004)$, with a positive effect of 2.73 yield. On the other hand, in Penicillium sp. 1 (R26) and Byssochlamys sp. trains, all factors and interaction positively influenced the enzyme index. In this sense, it is worth increasing oil concentration to obtain better El results. Similar results were found by Chen et al. (2019), where enzymatic assays revealed that the activity of manganese peroxidase in $P$. simplicissimum, was significantly induced in cultures supplemented with the contaminant when compared to the control (without contaminant). There are few reports in the literature regarding lignolytic enzymes production from petroleum products or even from crude oil in solid media. However, solid state fermentation (SSF) has been considered as a promising alternative for obtaining enzymes, as it offers a simpler fermentation medium, can provide higher productivity, allows greater control of microbial contamination, uses less water and consequently produces less waste liquid (Atagana et al. 2006). In addition, SSF has great potential for capital reduction in further processing and production, especially when filamentous fungi and industrial waste are used and, therefore, assists in the reuse and recovery of this waste, mitigating environmental impacts arising from improper disposal or accidents (Pires et al. 2020). Therefore, enzyme production in solid fermentation, with desirable characteristics for bioremediation, would help to develop bioprocess technology to obtain bioproducts useful in reducing pollutants toxicity.

For Pz, all effects were statistically significant, including factor 1 interaction with factor 2. However, the effect was negative, as expected, suggesting that the longer the time and the presence of oil, the lower the Pz value in Aspergillus sp., Penicillium sp. 1, Penicillium sp. 2, Penicillium sp. 1 (R26), and Byssochlamys 


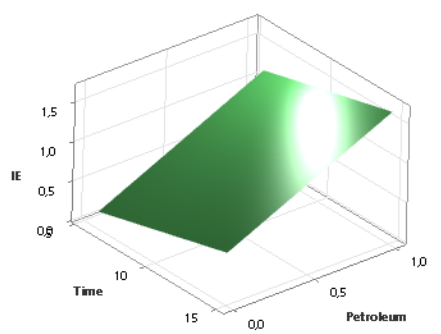

b
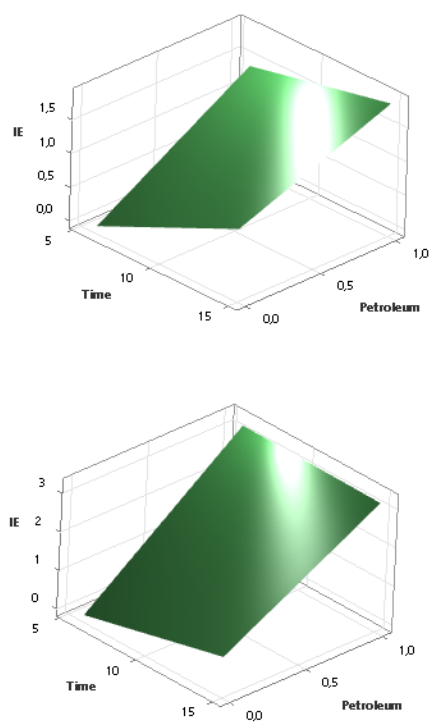

d

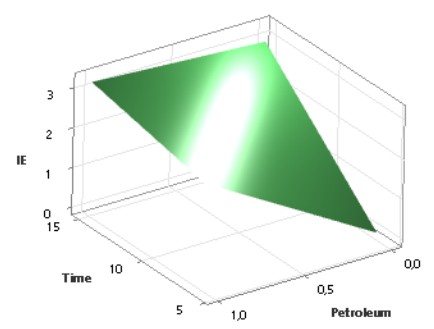

e

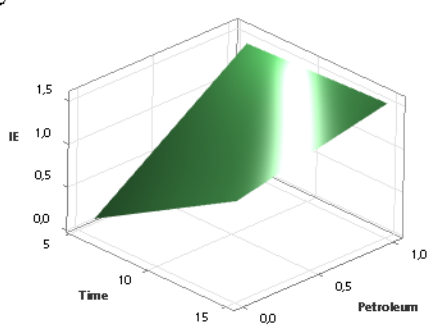

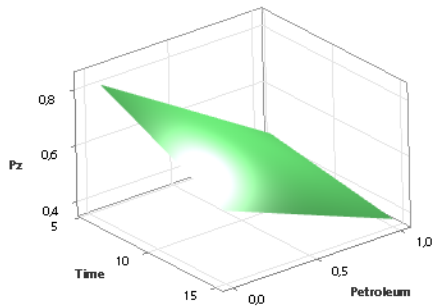
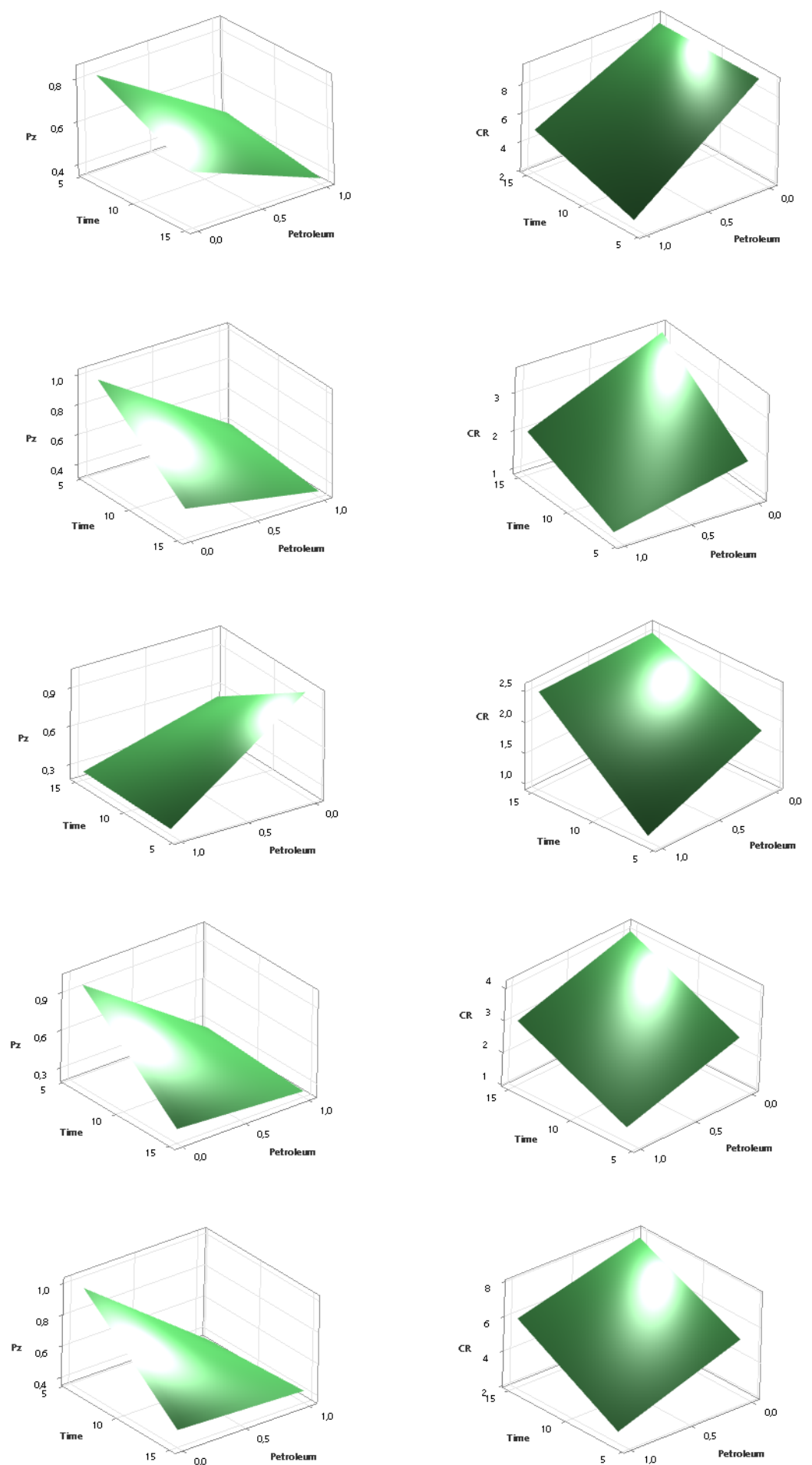

Figure 2. Three-dimensional response surface plot for MnP production using Aspergillus sp. (a), Penicilium sp. 1 (b), Penicilium sp. 2 (c), Penicilium sp. 1R26 (d) and Byssochlamys sp. (e) in solid fermentation. 
sp., consequently the enzyme activity will be inclined towards strongly positive. The Pz data corroborate the IE findings, showing an inversely proportional relationship. In this sense, the increase in IE and the reduction in $\mathrm{Pz}$ demonstrate better results for the evaluation of the studied strains. The Pz and IE indexes were not previously used to evaluate the production of $\mathrm{MnP}$ in solid culture medium, however it represents a simple and efficient strategy to indicate studied species potential. Therefore, this method makes it possible to increase the range of screening options for fungi that produce ligninolytic enzymes for laboratories which does not have robust equipment.

Penicillium sp. 2 growth showed significance ( $p=0.005$ ) for factor 1 , that is, it was influenced only by time with a positive effect. Apparently, both media did not provide a significant difference for the strain development. There was no change in growth, but there was an increase in IE when in BH medium. Factors effects and their combination for radial growth (CR) in Aspergillus sp. showed a $p$-value lower than 0.05 , and therefore, demonstrated significance in this strain development. On the other hand, the effect was negative in oil presence, that is, the strain grew more in the SDA culture medium than in $\mathrm{BH}$ medium, but IE values were favored. The same occurred for Penicillium sp. 1., Penicillium sp. 1 (R26) and Byssochlamys sp., however the factors interaction was not significant. Thus, even though these strains' growth has declined, the contaminant interference allowed to obtain better El and Pz values, emphasizing the evaluating importance of agreement between the variables studied. This result was also verified by Heinz et al. (2015), which highlights the need to evaluate the strain as a good enzyme producer, taking into consideration both microorganism growth in culture medium, as well as the enzyme index data.
A possible alternative to improve production in less time would be to increase the tested fungal biomass or change the contaminant concentration, evaluating degradation. Reports on fungi production in co-culture obtaining favored biomass over monoculture and the interaction between species reflects a greater tolerance to contaminant inhibitory effects (Hechmi et al. 2016), leading us to believe that these enzymes production limitations can be overcome by fermentation with multiple colonies. Such characteristics can be observed by other authors, such as Benoit-Gelber et al. (2017) where co-cultivation of A. niger with A. oryzae resulted in a more complex enzyme profile, Hu et al. (2011) obtained higher enzyme production from mixed cultivation of $A$. niger with P. chrysosporium, Zhao et al. (2019) reported the co-cultivation of $P$. oxalicum and $T$. reesei under solid state fermentation to produce enzymes of biotechnological interest and obtained yields up to 4 times higher and Hechmi et al. (2016) obtained increased production with $B$. nivea in cultivation with S. brumptii. In addition, microorganisms production in mixed cultures becomes a promising alternative for identifying new enzymes or compounds (Wösten 2019). Moreover, manganese peroxidase multiple production by the five strains can be encouraged to maximize the yield of the process.

\section{CONCLUSIONS}

Through the results obtained it was possible to infer that the studied fungi exhibited ligninolytic enzymatic activity, showing a capacity for the production of the enzyme manganese peroxidase with strongly positive enzyme activity values, with values of $I E>2$ for the genus Penicilium, thus providing a scope for their future application for the purpose of bioremediation 
of environments impacted by oil and / or its derivatives. The factorial design indicated that the enzyme index was increased in solid state fermentation when in $\mathrm{BH}$ medium plus oil, indicating the potential of this contaminant in the production of the MnP enzyme. Taking into account that fungi of marine origin can be an important resource for use in biotechnological processes and knowing the abilities of the strains studied to develop in the presence of petroleum hydrocarbons, the results of this study stimulate further investigations on the production of ligninolytic and other enzymes by Aspergillus sp., Penicilium sp. and Byssochlamys $\mathrm{sp}$. in addition to concentrating investigations on the characterization of these enzymes and on the optimization of the high biomass production process, in order to develop a bioproduct with multiple degradation functions.

\section{Acknowledgments}

The authors gratefully acknowledge the support from Shell Brasil through the "Research in Geomicrobiology: Microbial Biotechnology Applied to Petroleum Biodegradation and Recovery of Degraded Areas at Instituto de Geociências da Universidade Federal da Bahia (UFBA) - GEOQPETROL - GEOMICRO" - ANP 20720-9 project and the strategic importance of the support given by ANP through the R\&D levy regulation. To LEPETRO - Excellence in Petroleum, Energy and Environment Geochemistry. This study was financed in part by the Coordenação de Aperfeiçoamento de Pessoal de Nivel Superior (CAPES, Brazil, Finance Code 001). Thank you to Programa Institucional de Bolsas de Iniciação em Desenvolvimento Tecnológico e Inovação - PIBITI ( ${ }^{\circ}$ 31073) and Fundação de Amparo à Pesquisa do Estado da Bahia (FAPESB, no BOL0883 / 2017) and Fundação de Apoio à Pesquisa e à Extensão (FAPEX) for the granting of the scholarship.

\section{REFERENCES}

ABDULLAH OA, FATHI RA \& FADHEL MN. 2020. Use of fungi in bioremediation of contaminated sites with hydrocarbons. Plant Arch 20(2): 1406-1410.
ADRIO JL \& DEMAIN AL. 2014. Microbial enzymes: tools for biotechnological processes. Bio-molecules 4(1): 117-139.

AFTAB M, TAHIR A, ASIM T, \& MARYAM I. 2018. Optimization of cultural conditions for enhanced production of laccase by Aspergillus flavus Maf 0139. Biologia (Pakistan) 64(2): 247-255.

AGRAWAL N, VERMA P, SINGH RS \& SHAHI SK. 2017. Ligninolytic enzyme production by white rot fungi Podoscypha elegans strain FTG4. Int J Curr Microbiol App Sci 6(5): 2757-2764.

ASEMOLOYE MD, AHMAD R \& JONATHAN SG. 2018. Transcriptomic responses of catalase, peroxidase and laccase encoding genes and enzymatic activities of oil spill inhabiting rhizospheric fungal strains. Environ Pollut 235: 55-64.

ASEMOLOYE MD, TOSI S, DACCÒ C, WANG X, XU S, MARCHISIO MA, GAO W, JONATHAN SG \& PECORARO L. 2020. Hydrocarbon Degradation and Enzyme Activities of Aspergillus oryzae and Mucor irregularis Isolated from Nigerian Crude OilPolluted Sites. Microorganisms 8(12): 1912.

ASSES N, AYED L, HKIRI N \& HAMDI M. 2018. Congo red decolorization and detoxification by Aspergillus niger: removal mechanisms and dye degradation pathway. Biomed Res Int 2018.

ATAGANA HI, HAYNES RJ \& WALLIS FM 2006. Fungal bioremediation of creosote-contaminated soil: A laboratory scale bioremediation study using indigenous soil fungi. Water Air Soil Pollut 172(1): 201-219.

BANKOLE PO, SEMPLE KT, JEON BH \& GOVINDWAR SP. 2021. Impact of redox-mediators in the degradation of olsalazine by marine-derived fungus, Aspergillus aculeatus strain bpo2: Response surface methodology, laccase stability and kinetics. Ecotoxicol Environ Saf 208: 111742.

BECARELLI S, CHICCA I, SIRACUSA G, LA CHINA S, GENTINI A, LORENZI R, MUNZ G, PETRONI G, LEVIN DB \& DI GREGORIO S. 2019. Hydrocarbonoclastic Ascomycetes to enhance co-composting of total petroleum hydrocarbon (TPH) contaminated dredged sediments and lignocellulosic matrices. New Biotechnol 50: 27-36.

BEHBUDI G, YOUSEFI K \& SADEGHIPOUR Y. 2021. Microbial Enzymes Based Technologies for Bioremediation of Pollutions. J Environ Treat Tech 9(2): 463-469.

BENOIT-GELBER I, GRUNTJES T, VINCK A, VAN VELUW JG, WÖSTEN HA, BOEREN S, VERVOORT JJM \& DE VRIES RP. 2017. Mixed colonies of Aspergillus niger and Aspergillus oryzae cooperatively degrading wheat bran. Fungal Genet Biol 102: 31-37. 
BILAL M \& IQBAL HMN. 2020. Ligninolytic Enzymes Mediated Ligninolysis: An Untapped Biocatalytic Potential to Deconstruct Lignocellulosic Molecules in a Sustainable Manner. Catal Lett 150(2): 524-543.

BLANEY L. 2007. Magnetite (Fe304): Properties, Synthesis, and Applications. Lehigh Review 15(5): 33-81.

BONUGLI-SANTOS RC, DOS SANTOS VASCONCELOS MR, PASSARINI MR, VIEIRA GA, LOPES VC, MAINARDI PH \& SETTE LD. 2015. Marine-derived fungi: diversity of enzymes and biotechnological applications. Front Microbiol 6: 269.

BOSSO L, SCELZA R, TESTA A, CRISTINZIO G \& RAO MA. 2015. Depletion of pentachlorophenol contamination in an agricultural soil treated with Byssochlamys nivea, Scopulariopsis brumptii and urban waste compost: A laboratory microcosm study. Water Air Soil Pollut 226(6): 1-9.

CESKA M. 1971. Enzymatic catalysis in solidified media. Eur J Biochem 22 (2): 186-192.

CHEN SH, CHEOW YL, NG SL \& TING ASY. 2019. Biodegradation of triphenylmethane dyes by non-white rot fungus Penicillium simplicissimum: enzymatic and toxicity studies. Int J Environ Res 13(2): 273-282.

COELHO MAZ, SALGADO AM \& RIBEIRO BD. 2008. Tecnologia enzimática, 1a ed., EPUB, Rio de Janeiro.

DE SALAS F, CAÑADAS R, SANTIAGO G, VIRSEDA-JEREZ A, VIND J, GENTILI P, MARTÍNEZ AT, GUALLAR V, MUÑOZ IG \& CAMARERO S. 2019. Structural and biochemical insights into an engineered high-redox potential laccase overproduced in Aspergillus. Int J Biol Macromol 141: 855-867.

ELDRIDGE HC, MILLIKEN A, FARMER C, WENDLAND N, COWARD L, GREGORY DJ \& JOHNSON CM. 2017. Efficient remediation of $17 \alpha$-ethinylestradiol by Lentinula edodes (shiitake) laccase. Biocatal Agric Biotechnol 10: 64-68.

ELISASHVILI V, KACHLISHVILI E, KHARDZIANI T \& AGATHOS SN. 2010. Effect of aromatic compounds on the production of laccase and manganese peroxidase by whiterot basidiomycetes. J Ind Microbiol Biotechnol 37(10): 1091-1096.

EL-SHORA HM, YOUSSEF MM \& KHALAF SA. 2008. Inducers and inhibitors of laccase from Penicillium. Biotechnol 7(1): 35-42.

FERRARONI M, WESTPHAL AH, BORSARI M, TAMAYO-RAMOS JA, BRIGANTI F, DE GRAAFF LH \& VAN BERKEL WJ. 2017. Structure and function of Aspergillus niger laccase McoG. Biocatalysis 3(1): 1-21.
FUKUSHIMA Y \& KIRK TK. 1995. Laccase component of the Ceriporiopsis subvermispora lignin-degrading system. Appl Environ Microbiol 61(3): 872-876.

GLENN JK, AKILESWARAN L \& GOLD MH. 1986. Mn (II) oxidation is the principal function of the extracellular $\mathrm{Mn}$ peroxidase from Phanerochaete chrysosporium. Arch Biochem Biophys 251(2): 688-696.

GOVARTHANAN M, FUZISAWA S, HOSOGAI T \& CHANG YC. 2017. Biodegradation of aliphatic and aromatic hydrocarbons using the filamentous fungus Penicillium sp. CHY-2 and characterization of its manganese peroxidase activity. RSC advances 7(34): 20716-20723.

HANKIN L \& ANAGNOSTAKIS S L. 1975. The use of solid media for detection of enzyme production by fungi. Mycologia 67(3): 597-607.

HECHMI N, BOSSO L, EL-BASSI L, SCELZA R, TESTA A, JEDIDI N \& RAO MA. 2016. Depletion of pentachlorophenol in soil microcosms with Byssochlamys nivea and Scopulariopsis brumptii as detoxification agents. Chemosphere 165: 547-554.

HEINZ KGH, DOMINGUEZ AC, SILVA PR, BOTELHO TKR \& TAVARES LBB. 2015. Avaliação da atividade hidrolítica de microorganismos isolados de resíduo do processamento de papel. Rev Estud Ambient 16(2): 37-47.

HERNÁNDEZ-MARTÍNEZ R, GUTIÉRREZ-SÁNCHEZ G, BERGMANN CW, LOERA-CORRAL O, ROJO-DOMÍNGUEZ A, HUERTAOCHOA S \& PRADO-BARRAGÁN LA. 2011. Purification and characterization of a thermodynamic stable serine protease from Aspergillus fumigatus. Process Biochem 46(10): 2001-2006.

HU HL, VAN DEN BRINK J, GRUBEN BS, WÖSTEN HAB, GU JD \& DE VRIES RP. 2011. Improved enzyme production by cocultivation of Aspergillus niger and Aspergillus oryzae and with other fungi. Int Biodeter Biodegr 65(1): 248-252.

KADRI T, ROUISSI T, BRAR SK, CLEDON M, SARMA S \& VERMA M. 2017. Biodegradation of polycyclic aromatic hydrocarbons (PAHs) by fungal enzymes: A review. J Environ Sci 51: 52-74.

KELLNER H, LUIS P, PECYNA MJ, BARBI F, KAPTURSKA D, KRÜGER D \& HOFRICHTER M. 2014. Widespread occurrence of expressed fungal secretory peroxidases in forest soils. PLoS One 9(4): e95557.

KUMAR A \& CHANDRA R. 2020. Ligninolytic enzymes and its mechanisms for degradation of lignocellulosic waste in environment. Heliyon 6(2): e03170.

KUMAR R, KAUR J, JAIN S \& KUMAR A. 2016. Optimization of laccase production from Aspergillus flavus by design of experiment technique: Partial purification and characterization. J Genet Eng Biotechnol 14(1): 125-131. 
KURNIATI E, ARFARITA N, IMAI T, HIGUCHI T, KANNO A, YAMAMOTO K \& SEKINE M. 2014. Potential bioremediation of mercurycontaminated substrate using filamentous fungi isolated from forest soil. J Environ Sci 26(6): 1223-1231.

KUWAHARA M, GLENN JK, MORGAN MA \& GOLD MH. 1984. Separation and characterization of two extracellular H2O2-dependent oxidases from ligninolytic cultures of Phanerochaete chrysosporium. FEBS Lett 169(2): 247-250.

LI C, ZHAO X, WANG A, HUBER GW \& ZHANG T. 2015. Catalytic transformation of lignin for the production of chemicals and fuels. Chem Rev 115(21): 11559-11624.

LI Q, LIU J \& GADD GM. 2020. Fungal bioremediation of soil co-contaminated with petroleum hydrocarbons and toxic metals. Appl Microbiol Biotechnol 104(21): 8999-9008.

LIMA DF, DE OLIVEIRA OMC, GERIS RMS, TRIGÜIS JA, QUEIROZ AFS, CRUZ MJM \& BARRETO IS. 2017. Isolation and selection of fungi for degrading saturated hydrocarbons, aromatic hydrocarbons and NSO compounds. Open J Yangtze Oil Gas 2(1): 10-26.

LIMA DF, DE OLIVEIRA OMC, QUEIROZ AFS, OLIVEIRA EJF, DANTAS CP, DE MENEZES-NETO AA \& PINCHEMEL JPD. 2021. Consórcio microbiano misto degradador de óleos parafínicos da bacia do Recôncavo-Bahia-Brasil. Patente BR 102021 0023414.

LIMA DF, DE SOUZA QUEIROZ AF, DANTAS CP, PALMEIRA JBA, COSTA CR \& DE OLIVEIRA OMC. 2018. The Small-Scale Microbial Processes for Remediation of Sediments Contaminated with Hydrocarbons. In: Microbial Action on Hydrocarbons. Springer, Singapore, 255-297.

LIN JE, CHANG DC, SHEN GJ \& WANG HY. 1991. Correlations among several screening methods used for identifying wood-decay fungi that can degrade toxic chemicals. Biotechnol Tech 5(4): 275-280.

MACIEL CDCS, DE SOUZA MA, DE GUSMÃO NB \& DE CAMPOSTAKAKI GM. 2010. Produção de enzimas do sistema lignolítico por fungos filamentosos isolados de locais impactados por petroderivados. Exacta 8(3): 299-305.

MACIEL MJM \& RIBEIRO HCT. 2010. Industrial and biotechnological applications of ligninolytic enzymes of the basidiomycota: A review. Electron J Biotechnol 13(6): 14-15.

MANN J, MARKHAM JL, PEIRIS P, NAIR N, SPOONER-HART RN \& HOLFORD P. 2010. Screening and selection of fungi for bioremediation of olive mill wastewater. World J Microbiol Biotechnol 26(3): 567-571.

M'BAREK HN, TAIDI B, SMAOUI T, AZIZ MB, MANSOURI A \& HAJJAJ H. 2019. Isolation, screening and identification of ligno-cellulolytic fungi from northern central Morocco. Biotechnol Agron Soc Environ 23(4): 207-217.

NATHAN VK, KANTHIMATHINATHAN SR, RANI ME, RATHINASAMY G \& KANNAN ND. 2018. Biobleaching of waste paper using lignolytic enzyme from Fusarium equiseti VKF2: a mangrove isolate. Cellulose 25(7): 4179-4192.

OGOLA HJ O, ASHIDA H, ISHIKAWA T \& SAWA Y. 2015. Explorations and applications of enzyme-linked bioremediation of synthetic dyes. In: Shiomi N (Ed), Advances in Bioremediation of Wastewater and Polluted Soil. InTech DTP Team, Croatia, p. 111-144.

PALUdO GB, DE ABREU-LIMA TL \& CARREIRO SC. 2019. Potencial enzimático de leveduras isoladas de folhas em decomposição. Acta Tecnológica 13(2): 65-77.

PIRES GBP, VASCONSELOS PG, AMBROZIM FM \& PINHEIRO IR. 2020. Estudo comparativo de produção de celulases variando-se as condições de cultivo na fermentação em estado sólido. Braz J Dev 6(11): 93305-93315.

PRICE MF, WILKINSON ID \& GENTRY LO. 1982. Plate method for detection of phospholipase activity in Candida albicans. Sabouraudia: J Med Vet Mycol 20(1): 7-14.

QUEIROZ C \& DE SOUZA ACB. 2020. Produção de enzimas hidrolíticas por fungos filamentosos em diferentes substratos sólidos. Braz Jo Dev 6(7): 51849-51860.

RADWAN, GUNASEKERA TS \& RUIZ ON. 2018. Draft genome sequence of Byssochlamys sp. isolate BYSS01, a filamentous fungus adapted to the fuel environment. Genome Announc 6: 10.

RAO MA, SCELZA R, ACEVEDO F, DIEZ MC \& GIANFREDA L. 2014. Enzymes as useful tools for environmental purposes. Chemosphere 107: 145-162.

RATHER LJ, AKHTER S \& HASSAN QP. 2018. Bioremediation: green and sustainable technology for textile effluent treatment. In: Sustainable innovations in textile chemistry and dyes. Springer, Singapore, p. 75-91.

REIS NS, BRITO AR, PACHECO CS, COSTA LC, GROSS E, SANTOS TP \& FRANCO M. 2019. Improvement in menthol extraction of fresh leaves of Mentha arvensis by the application of multi-enzymatic extract of Aspergillus niger. Chem Eng Commun 206(3): 387-397.

REZENDE EDF, COUTO FA, BORGES JG, SILVA DMD \& BATISTA LR. 2013. Potencial enzimático e toxigênico de fungos isolados de grãos de café. Coffee Sci 8(1): 69-77.

SALDARRIAGA-HERNÁNDEZ S, VELASCO-AYALA C, FLORES PLI, DE JESÚS ROSTRO-ALANIS M, PARRA-SALDIVAR R, IQBAL HM \& CARRILLO-NIEVES D. 2020. Biotransformation of lignocellulosic biomass into industrially relevant 
products with the aid of fungi-derived lignocellulolytic enzymes. Int J Biol Macromol 161: 1099-1116.

SALEM SS, MOHAMED A, EL-GAMAL M, TALAT M \& FOUDA A. 2019. Biological decolorization and degradation of azo dyes from textile wastewater effluent by Aspergillus niger. Egypt J Chem 62(10): 1799-1813.

SCHNEIDER WDH, FONTANA RC, MENDONÇA S, DE SIQUEIRA FG, DILLON AJP \& CAMASSOLA M. 2018. High level production of laccases and peroxidases from the newly isolated whiterot basidiomycete Marasmiellus palmivorus VE111 in a stirred-tank bioreactor in response to different carbon and nitrogen sources. Process Biochem 69: 1-11.

SHARMA B, DANGI AK \& SHUKLA P. 2018. Contemporary enzyme based technologies for bioremediation: a review. J Environ Manage 210: 10-22.

SIDWABA U, NTSHONGONTSHI N, FELENI U, WILSON L, WARYO T \& IWUOHA El. 2019. Manganese Peroxidase-Based ElectroOxidation of Bisphenol A at Hydrogellic PolyanilineTitania Nanocomposite-Modified Glassy Carbon Electrode. Electrocatalysis 10(4): 323-331.

STAMFORD TLM, ARAÚJO JM \& STAMFORD NP. 1998. Atividade enzimática de microrganismos isolados do jacatupé (Pachyrhizus erosus L. Urban). Food Sci Technol 18(4): 382-385.

SZKLARZ GD, ANTIBUS RK SINSABAUGH RL \& LINKINS AE. 1989. Production of phenol oxidases and peroxidases by wood-rotting fungi. Mycologia 81(2): 234-240.

THEERACHAT M, GUIEYSSE D, MOREL S, REMAUD-SIMÉON M \& CHULALAKSANANUKUL W. 2019. Laccases from marine organisms and their applications in the biodegradation of toxic and environmental pollutants: a review. Appl Biochem Biotechnol 187(2): 583-611.

VALLECILLOS L, SADEF Y, BORRULL F, POCURULL E \& BESTER K. 2017. Degradation of synthetic fragrances by laccasemediated system. J Hazard Mater 334: 233-243.

VIPOTNIK Z, MICHELIN M \& TAVARES T. 2021. Ligninolytic enzymes production during polycyclic aromatic hydrocarbons degradation: effect of soil pH, soil amendments and fungal co-cultivation. Biodegradation 32(2): 193-215.

WEI R \& ZIMMERMANN W. 2017. Microbial enzymes for the recycling of recalcitrant petroleum-based plastics: how far are we? Microb Biotechnol 10(6): 1308-1322.
WONG DWS. 2009. Structure and action mechanism of ligninolytic enzymes. Appl Biochem Biotechnol 157(2): 174-209.

WÖSTEN HA. 2019. Filamentous fungi for the production of enzymes, chemicals and materials. Curr Opin Biotechnol 59: 65-70.

YE C, CHING TH, YOZA BA, MASUTANIS \& LI QX. 2017. Cometabolic degradation of blended biodiesel by Moniliella wahieum Y12T and Byssochlamys nivea M1. Int Biodeter Biodegr 125: 166-169.

ZENG S, QIN X \& XIA L. 2017. Degradation of the herbicide isoproturon by laccase-mediator systems. Biochem Eng J 119: 92-100.

ZHANG H, ZHANG X \& GENG A, 2020. Expression of a novel manganese peroxidase from Cerrena unicolor BBP6 in Pichia pastoris and its application in dye decolorization and PAH degradation. Biochem Eng J 153: 107402.

ZHAO X, YI S \& Li H. 2019. The optimized co-cultivation system of Penicillium oxalicum 16 and Trichoderma reesei RUT-C30 achieved a high yield of hydrolase applied in second-generation bioethanol production. Renew Energy 136: 1028-1035.

\section{SUPPLEMENTARY MATERIAL}

Figure S1. Phylogenetic tree based on ITS analyzes showing closest relatives of isolates of fungi derived from the sea (model of neighbors' union and bootstrap of 1000 replicates).

Table SI. Molecular identification of filamentous fungi from mangrove sediment in the bay of Todos os Santos, Brazil

\begin{abstract}
How to cite
DANTAS CP, PINCHEMEL JPD, JESUS GM, PIMENTEL MB, OLIVEIRA OMC, QUEIROZ AFS \& LIMA DF. 2021. Bioprospection of ligninolytic enzymes from marine origin filamentous fungi. An Acad Bras Cienc 93: e20210296. DOI 10.1590/0001-3765202120210296.
\end{abstract}

Manuscript received on February 24, 2021; accepted for publication on May 16, 2021

\section{CAMILA P. DANTAS}

https://orcid.org/0000-0002-1462-2594 
JOÃO PEDRO D. PINCHEMEL

https://orcid.org/0000-0002-7484-3698

\section{GISELE M. DE JESUS}

https://orcid.org/0000-0001-6558-1297

\section{MILENA B. PIMENTEL}

https://orcid.org/0000-0003-4704-6498

\section{OLIVIA MARIA C. OLIVEIRA}

https://orcid.org/0000-0002-8945-3000

ANTÔNIO FERNANDO S. QUEIROZ

https://orcid.org/0000-0002-3473-4462

\section{DANUSIA F. LIMA}

https://orcid.org/0000-0002-8412-9148

Universidade Federal da Bahia, Instituto de Geociências, Departamento de Oceanografia, Av. Adhemar de

Barros, s/n, Ondina, 40170-110 Salvador, BA, Brazil

\section{Correspondence to: Camila Paim Dantas}

E-mail:camilapdantas@gmail.com

\section{Author contributions}

All authors contributed to the development of the manuscript: Camila Paim Dantas - conceptualization (lead); investigation (supporting); resources (supporting); formal analysis (lead); writing - original draft (supporting); supervision (lead); writing - review \& editing (lead); João Pedro Dantas Pinchemel conceptualization (equal), investigation (lead), resources (lead), writing - original draft (lead), writing - review \& editing (equal); Gisele Moraes de Jesus - conceptualization (supporting); investigation (supporting); resources (supporting); writing - review \& editing (supporting); Milena Barbosa Pimentel conceptualization (equal); investigation (supporting); resources (supporting); writing - review \& editing (supporting); Antônio Fernando Souza Queiroz - funding acquisition (equal); Writing - review \& editing (supporting); Olívia Maria Cordeiro de Oliveira - funding acquisition (equal); writing - review \& editing (supporting); Danusia Ferreira Lima - funding acquisition (supporting); project administration (lead); supervision (supporting); writing - review \& editing (supporting).

\section{(cc) BY}

